\title{
Pendekatan Keruangan Dalam Kajian Permukiman Gua
}

\section{Indah Asikin Nurani}

Keywords: spatial, archaeology, cave, settlement, prehistory, model, pattern

\section{How to Cite:}

Nurani, I. A. (1997). Pendekatan Keruangan Dalam Kajian Permukiman Gua. Berkala Arkeologi, 17(1), 14-23. https:// doi.org/10.30883/jba.v17i1.765

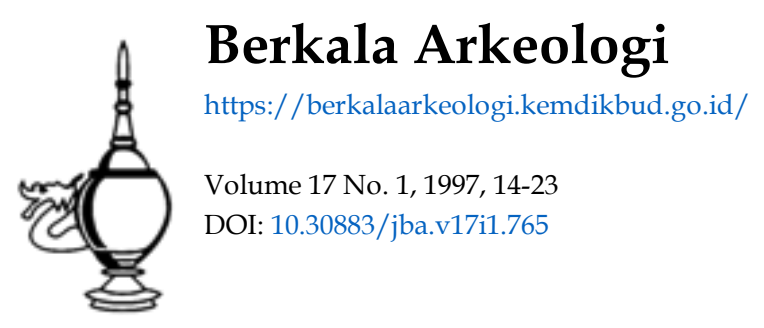

\section{(c) (1) (9) (2)}

This work is licensed under a Creative Commons Attribution-NonCommercial-ShareAlike 4.0 International License. 


\title{
PENDEKATAN KERUANGAN DALAM KAJIAN PERMUKIMAN GUA
}

\author{
Indah Asikin Nurani \\ (Balai Arkeologi Yogyakarta)
}

\section{Pendahuluan.}

\section{I.1. Latar Belakang Masalah}

Selama ini penelitian tentang permukiman masih dititikberatkan pada jangkauan penjajagan atau masih bersifat eksploratif. Sehubungan dengan kondisi tersebut, menarik perhatian untuk dikaji lebih mendalam tentang studi permukiman. Terminologi pola permukiman yang selama ini diketahui meliputi beberapa pengertian yaitu :

a) cara manusia menata, mengatur, dan menyiasati kehidupannya di muka bumi dalam hubungannya dengan lingkungan fisiografi (Chang, 1968)

b) cara manusia menempatkan diri di muka bumi dalam kaitannya dengan pengaturan tempat timggal (J.R. Parson)

c) pola yang terjadi pada pengaturan tempat tinggal dan satuan-satuan komunitas yang ditata secara keruangan di muka bumi (Vogt).

Dari pengertian tersebut di atas tampaknya pengertian E.Z. Vogt perlu ditelaah lebih mendalam sehubungan dengan keruangan dan tingkat keruangan yang terdapat dalam suatu pola permukiman.

Pembahasan mengenai studi permukiman erat kaitannya dengan tingkat keruangan. Dalam studi keruangan dikenal adanya tiga tingkat keruangan, yaitu ruang tingkat mikro, semi mikro (meso), dan ruang tingkat makro. Dalam ruang tingkat mikro dipelajari tentang hubungan antar ruang dalam satu unit bangunan. Tingkat ruang semi mikro (meso) mempelajari hubungan antar unit ruang yang dapat dikelompokkan dalam satu komunitas (situs). Adapun tingkat ruang makro mempelajari hubungan antar situs yang meliputi beberapa komunitas, dalam hal ini cakupan kawasan (Clarke, 1977). Selama ini penelitian mengenai tata ruang dari beberapa tingkat tersebut masih belum sepenuhnya diminati dalam mengkaji permukiman kehidupan masa lalu, terutama telaah mengenai tata ruang gua.

Pola permukiman gua merupakan studi tersendiri yang menarik perhatian sehubungan dengan studi keruangan. Sebagainaana telah diketahui bahwa gua merupakan gejala alam yang disediakan alam untuk manusia. Dapat atau tidaknya potensi alam dimanfaatkan dan dieksploitasi oleh manusia sangat ditentukan oleh "keahlian"

Pemah dipresentasikan dalam Evaluasi Hasil Penelitian Arkeologi. Palembang 10 - 16 Oktober 1994. 
manusia itu sendiri. Hal tersebut tercermin dan berkaitan dengan pola kehidupan dan kebutuhan hidup manusia penghuninya itu sendiri.

Sebagaimana telah diketahui bersama, suatu lahan gua yang tersedia sangatlah terbatas, sehingga menarik untuk ditelaah lebih mendalam. Ruangan gua yang terbatas tersebut diharapkan dapat dijadikan patokan sebagai awal dalam kajian mengenai pola permukiman dengan pendekatan melalui arkeologi ruang. Selama ini penelitian mengenai pola permukiman gua dilakukan dalam tahap penentuan tipe aktivitas penghuni gua, yang dititikberatkan pada unit analisis tertentu seperti artefak dan ekofak yang terkandung dalam gua tersebut. Sementara itu penelitian mengenai rekonstruksi pola dan cara hidup serta pemanfatan lahan gua yang tersedia belum pernah dilakukan. Dengan demikian pola serta model yang dilakukan dan telah dikenal manusia pada masa itu menarik perhatian untuk dikaji dan dicermati.

Tulisan ini berupaya untuk mengungkapkan beberapa hal sebagai berikut :

1. bagaimana cara dan strategi yang digunakan dalam mengkaji pola permukiman gua sehubungan dengan pengaturan tata ruang gua?

2. pendekatan apa yang tepat untuk mengungkap tata ruang gua?

3. strategi dan metode yang bagaimana yang sebaiknya digunakan, selain itu teknik apa yang cocok dalam penjaringan data untuk mengungkap tujuan penelitian tersebut?.

\section{I.2. Pendekatan Studi}

Dalam studi arkeologi ruang dikenal 3 tingkat ruang yaitu ruang tingkat mikro, semi mikro, dan ruang tingkat makro. Dalam kajian studi arkeologi ruang selama ini masih terdapat kontroversi pembagian tingkat keruangan, yaitu seperti yang disampaikan oleh Subroto yang membagi dalam dua tingkat ruang yaitu mikro dan makro struktur. Sedangkan Mundarjito membagi dalam tiga tingkat ruang yaitu ruang tingkat mikro, semi mikro (meso), dan tingkat makro.

Studi arkeologi ruang sebagaimana yang diungkapkan oleh Subroto didasarkan pada pengertian berikut. Dalam mikro structure dipelajari mengenai bangunan secara individu maupun suatu situs dimana bangunan-bangunan tersebut disusun oleh suatu komunitas. Di dalam pola makro terdapat gambaran tentang hubungan antara komunitas di suatu situs dengan komunitas di situs yang lain. Dengan demikian pola permukiman makro menunjukkan distribusi situs-situs permukiman yang ada beserta perubahan-perubahan yang terjadi oleh faktor waktu. Kedua bentuk aktivitas tersebut sesuai sekali dengan konsep permukiman yang diajukan oleh Sanders, yaitu pola permukiman komunitas dan pola permukiman zonal (Subroto, 1983).

Mundarjito menyatakan adanya tiga tingkat ruang didasarkan pada hubungan fungsional ruang tersebut. Pada tingkat mikro dalam studi permukiman yang 
dimaksud adalah pada satu unit bangunan dengan komponen-komponen yang mendukungnya, pada tingkat ruang semi mikro merupakan satu situs atau satu komunitas yang terdiri dari beberapa unit bangunan, sedangkan tingkat makro adalah hubungan antar situs dalam satu kawasan atau wilayah (Mundarjito, 1990). Menurut Mundarjito pembagian tingkat ruang tersebut dimaksudkan untuk mengungkap pola permukiman dengan segala aspeknya yang dapat dipersingkat sebagai berikut, pada tingkat mikro pola yang dipelajari adalah persebaran ruangan, dan hubungan antar ruang di dalam satu unit bangunan. Hal tersebut untuk mengetahui antara lain struktur sosial (keluarga) yang didasarkan pada data seperti hirarki ruang, fungsi ruang, dan gaya bangunan. Dalam tingkat semi mikro mempelajari persebaran dan hubungan antara bangunan-bangunan di dalam satu situs untuk mengetahui antara lain struktur sosial (komunitas), ekonomi, politik, dan agama. Sedangkan tingkat makro mempelajari persebaran dan hubungan antar situs di dalam satu wilayah untuk mengetahui antara lain struktur sosial (masyarakat) politik, ekonomi, dan kemampuan teknologi.

Berdasarkan uraian di atas dapatlah diungkapkan di sini kemungkinan-kemungkinan yang terjadi dalam pola permukiman gua. Kedua pembagian tingkat keruangan tersebut bisa saja terjadi, hal tersebut didasarkan pada beberapa alternatif. Alternatif pertama pada satu unit bangunan dalam hal ini satu gua hunian merupakan satu gua yang berfungsi sebagai satu ruangan tertentu untuk kebutuhan satu komunitas, sehingga satu gua mencerminkan suatu aktivitas tertentu seperti sebagai dapur, bengkel, dan base camp. Alternatif kedua adalah dalam satu gua hunian merupakan satu gua yang digunakan untuk aktivitas satu keluarga, sehingga masing-masing gua mencerminkan berbagai kegiatan dalam satu keluarga. Dari uraian tersebut dapatlah digambarkan sebagai berikut.
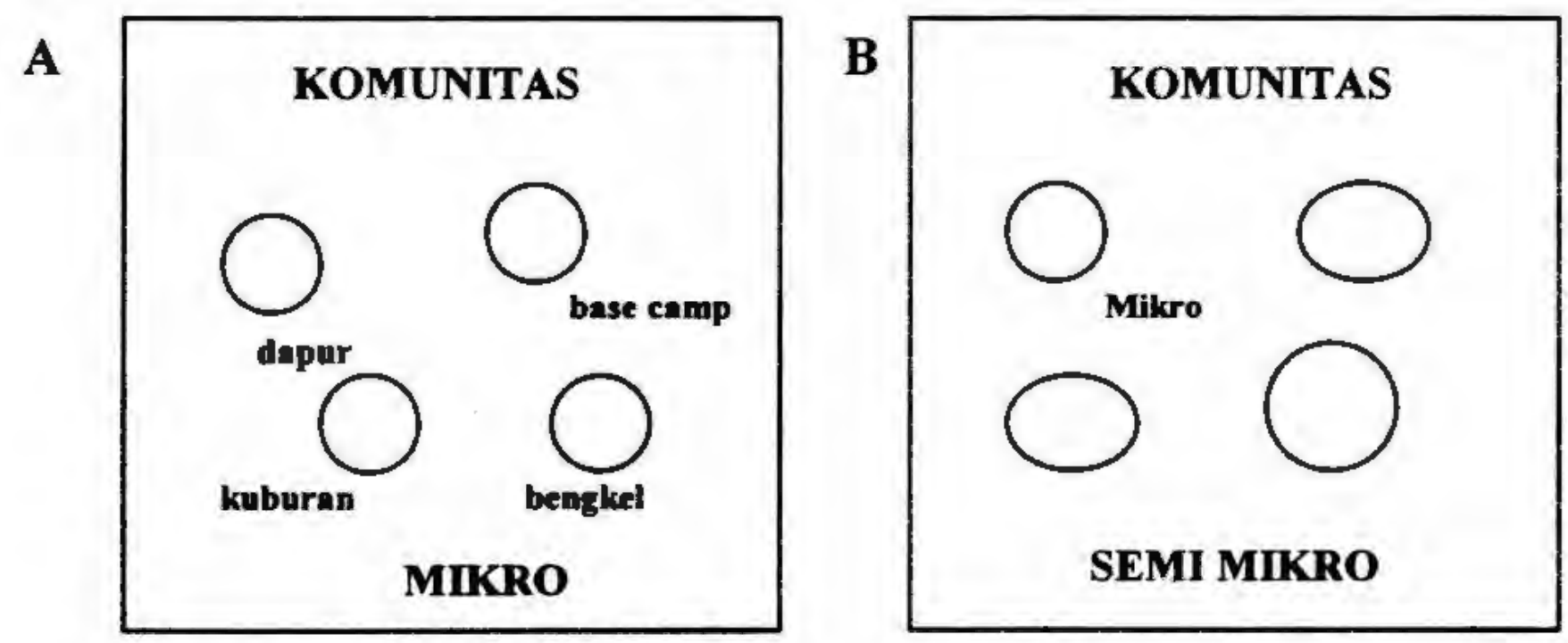
A. Gambaran ini menunjukkan bahwa satu unit gua mempunyai fungsi tersendiri dan digunakan bagi kepentingan satu komunitas. Sehingga model permukiman gua tersebut tidak mengenal ruang tingkat semi mikro.

B. Gambaran ini menunjukkan bahwa satu unit gua merupakan gua yang digunakan sebagai aktivitas satu keluarga yang terdiri dari berbagai aktivitas hidup seharihari penghuninya. Sehingga dalam satu unit gua menunjukkan segala aktivitas penghuninya secara lengkap. Dalam hal ini satu unit gua merupakan ruang tingkat mikro, selanjutnya sekelompok gua-gua tingkat mikro tersebut merupakan ruang tingkat semi mikro (satu situs atau satu komunitas).

\section{I.3. Pengertian dan determinasi keruangan dalam permukiman gua.}

Permukiman gua menarik untuk diungkapkan, khususnya mengenai tata ruang sehubungan dengan pemanfaatan lahan gua yang tersedia. Sebagaimana diketahui gua merupakan rumah tinggal sebagaimana bangunan-bangunan rumah tangga lainnya. Perbedaan terletak pada fakta bahwa gua merupakan kondisi alam yang sudah tersedia tanpa mengalami campur tangan manusia, sehingga gua tidak menyediakan ruangan yang seragam dan sesuai dengan harapan manusia penghuninya. Pemanfaatan lahan yang tersedia di dalam gua menarik untuk dikaji lebih mendalam, hal tersebut dimaksudkan untuk mengetahui seberapa jauh manusia penghuninya mampu mengeksploitasi semaksimal mungkin untuk selanjutnya digunakan sebagai kegiatan sehari-hari dalam kehidupannya.

Dari uraian tersebut di atas, tampak jelas bahwa pemanfaatan lahan gua mencerminkan segala aspek kehidupan penghuninya pada masa lalu. Dengan kata lain penelitian mengenai pemanfaatan lahan gua dapat menjawab seberapa jauh "keahlian" manusia masa lalu dalam memanfaatkan dan mengeksploitasi lahan yang tersedia guna kebutuhan dan aktivitas sehari-harinya.

Dalam penjaringan data dan persyaratan yang harus dipenuhi dalam mengkaji dan menjawab permasalahan tata ruang gua tingkat mikro, hal-hal yang perlu diperhatikan adalah sebagai berikut : a) penentuan kotak gali yang mewakili bagian per-lahan, seperti bagian dalam, ujung, sudut kanan, sudut kiri, dan bagian belakang; b) kondisi gua yang memiliki beberapa ruang tentunya dapat ditunjukkan dengan beberapa kotak gali terpilih, sehingga akan diketahui tentang fungsi dari masingmasing ruangan; dan c) pengkelompokkan temuan baik secara himpunan maupun lepas, dengan demikian dari data temuan yang tercakup akan didapatkan suatu interpretasi yang bisa menjelaskan mengenai ruang dan waktu. 


\section{Metode \\ II.1. Metode pengumpulan data dalam mengkaji pola keruangan gua. \\ II.1.1. Survei}

Survei ditujukan untuk mengeksplorasi seluruh gua atau ceruk hunian dalam satu komunitas atau satu kompleks (ruang tingkat semi mikro). Pengumpulan data melalui survei dalam tingkat semi mikro perlu diperhatikan hal-hal sebagai berikut : a) mengamati seluruh kompleks gua yang ada. sebab sebagian besar merupakan kompleks gua dalam bentang lahan yang sama (perbukitan kapur); b) menentukan gua-gua terpilih sebagai sampel gua dalam satu komunitas gua hunian, hal tersebut dapat dilakukan dengan mengadakan pengkaisan: dan c) menjajagi secara mendalam gua-gua terpilih tersebut untuk selanjumya dilakukan tahap berikutnya yaitu ekskavasi.

\section{II.1.2. Ekskavasi}

Sebagaimana telah diketahui bersama teknik ekskavasi yang umum dilakukan selama ini adalah teknik spit. Kelebihan teknik ini adalah penggalian dilakukan dengan interval tertentu yang selanjutnya dapat diketahui semua temuan yang terekam, selain itu diketahui pada spit berapa terjadi perubahan lapisan tanah (stratigrafi). Namun sejauh ini terdapat beberapa kelemahan yang dialami, yaitu dengan teknik ini tidak dapat terlacak data mana saja yang berasal dari suatu lapisan tanah tertentu, sebab sebagian besar sudah teraduk pada satu spit, padahal sering terjadi perubahan lapisan tanah pada satu spit tertentu. Selain itu dalam satu spit tidak dapat dibedakan keletakan temuan pada ruang terkecil dalam suatu kegiatan. Kelemahan tersebut dapat menyebabkan kekeliruan dalam penafsiran atau interpretasi.

Pada hakekatnya segala sesuatu yang dilakukan oleh manusia (kegiatan) akan menghasilkan permukaan yang tidak merata. Sehingga dalam mengungkapkan semua itu diperlukan teknik tertentu dalam melacaknya. Untuk mengkaji dan menjabarkan tentang pemanfaatan lahan gua sehubungan dengan telaah tata ruang gua, teknik yang sesuai dan cocok digunakan adalah teknik lot. Teknik sebetulnya merupakan teknik ekskavasi yang tidak asing lagi bagi arkeolog Amerika (barat) sebab teknik tersebut merupakan teknik penjaringan data yang selalu digunakan, oleh sebab itu tidak ada bahasan tersendiri mengenai teknik tersebut. Prinsip mendasar dalam suatu ekskavasi adalah membuka dan melaporkan atau mendata masing-masing layer atau featur dalam menyusun dari apa yang terendapkan pada area yang memungkinkan (secara horisontal) (Philip, 1982).

Pengertian lot adalah kumpulan benda yang dianggap satu fungsi dalam suatu kegiatan tertentu. Hal tersebut untuk mempermudah dalam penganalisisan. Beberapa pertimbangan mengapa ekskavasi dengan teknik lot yang dipilih adalah sebagai berikut.

- Lot merupakan tingkat ruangan terkecil dalam menelaah suatu pola permukiman. 
- Untuk mengetahui tata ruang suatu aktivitas perlu penjabaran mengenai manfaat ruangan terkecil tersebut.

- Untuk mengetahui luas lahan (ruang) yang digunakan dalam suatu aktivitas.

- Untuk mengetahui lamanya suatu lahan digunakan (waktu) yaitu secara vertikal dan seberapa lama suatu lahan atau ruang digunakan dapat diketahui melalui kedalaman dari data (gejala) yang menunjukkan suatu aktivitas tertentu.

Secara garis besar dapat diketahui bahwa ekskavasi dengan teknik lot akan menghasilkan suatu interpretasi ruang dan waktu terkecil yang tercermin dalam temuan berupa gejala aktivitas secara horisontal dan vertikal.

Dalam teknik lot terdapat dua jenis sistem yaitu :

- Natural level arbitrary : dalam cara ini adalah didasarkan pada pengambilan keputusan si arkeolog itu sendiri dalam menentukan perbedaan lot (gejala terkecil).

- Level combination : dalam cara ini adalah menggabungkan antara teknik spit dengan teknik lot. Ini terjadi apabila dalam satu lot mempunyai lapisan yang tebal. Sehingga dalam satu lot dibantu dengan teknik spit yaitu menggunakan interval.

\section{II.2. Konsekuensi operasional penerapan ekskavasi dengan sistem lot.} II.2.1. Prinsip pengumpulan data - ketetapan menentukan lot per lot. Sebagaimana telah dijelaskan di atas teknik lot adalah teknik ekskavasi yang menitikberatkan pada penilaian subyektivitas arkeolog sendiri dalam mengambil keputusan. Prinsip, segala keputusan dapat diinformasikan dan dijabarkan dalam pertimbangan-pertingan tertentu.

Dalam menentukan lot per lot, secara prinsip yang seharusnya diperhatikan adalah pengambilan keputusan yang masuk akal dan dapat diinformasikan secara lugas dan komunikatif. Selain itu pengambilan keputusan tersebut didasarkan pada suatu dasar yang dapat dipertanggungjawabkan dan mencerminkan suatu gejala aktivitas tertentu. Dengan demikian secara tegas dapat disimpulkan bahwa pengambilan keputusan haruslah didasarkan pada penalaran yang bertanggung jawab dan melalui pengamatan cermat terhadap semua gejala.

Setiap lot semestinya merupakan kekhususan temuan (gejala). Hal-hal yang dianggap penting dan khusus dapat dijabarkan sebagai berikut, yang nantinya dapat dijadikan sebagai satu lot tertentu, yaitu :

a) sekelompok temuan yang mencerminkan gejala tertentu,

b) merupakan lapisan tanah tertentu; dan atau

c) merupakan suatu temuan lepas atau himpunan. 


\section{II.2.2. Pendokumentasian yang meliputi penggambaran dan pemotretan (fotografi).}

Dalam ekskavasi teknik lot ini hal yang paling rumit adalah pendokumentasian berupa gambar dan foto. Dapat dijelaskan di sini satu per satu mengenai hal tersebut.

\section{II.2.2.1. Penggambaran}

Dalam hal ini dibagi dalam 2 tahap yaitu lapangan dan pasca lapangan. Dalam tahap lapangan hal-hal yang harus dilakukan adalah sebagai berikut.

Setiap perubahan lot dan gejala yang ditemukan haruslah dapat terekam dalam kertas milimeter, setidaknya dalam bentuk sket. Pengukuran dilakukan dengan cara X, Y, Z dimana $\mathrm{X}$ merupakan pengukuran dari dinding barat, $\mathrm{Y}$ pengukuran dari dinding selatan, dan pengukuran $\mathrm{Z}$ adalah kedalaman. Dengan demikian dapat diwujudkan dalam penggambaran secara tiga dimensi. Sedangkan pada tahap pasca lapangan adalah menganalisis dan menyajikan dalam gambar secara lot per lot yang selanjutnya disajikan secara tiga dimensi di atas kertas kalkir.

\section{II.2.2.2. Pemotretan}

Dalam pemotretan hal-hal yang perlu diperhatikan adalah merekam keseluruhan lot sebelum diperdalam pada lot berikutnya. sehingga seluruh lot dapat terekam baik melalui foto maupun penggambaran. Prinsip. pemotretan merupakan alat bantu setelah penggambaran. Mengenai bagaimana pemotretan dilakukan pada awal atau akhir lot dapat dilakukan sesuai kebutuhan untuk penganalisisan selanjutnya.

Dalam penomoran lot per lot, perlu diperhatikan hal-hal sebagai berikut. Sebagaimana dijelaskan di atas bahwa lot merupakan ruang terkecil atau dengan kata lain merupakan sumber minimum unit dalam suatu kegiatan. Setiap perubahan lot diharapkan untuk mampu mengontrol permukaan, sehingga dapat terekam data secara kelompok (himpunan) artefak maupun sebuah gejala (lepas) dari sebuah kekhususan area atau secara terkonsentrasi. Pembedaan lot didasarkan pada interval informasi (Sharer, 1980) yang dapat didasarkan pada :

- masing-masing level lot dibedakan dari matriks yang terdiri dari bagian-bagian sejenis;

- jika terjadi perubahan dalam pengamatan karakter matriks seperti warna dan tekstur tanah; dan

- masing-masing perubahan layer (stratum) dibedakan secara jelas dalam satu lot.

Dalam pelabelan lot per lot dapat diacu pada beberapa hal yaitu sebagai contoh $3 \mathrm{~F} / 4$ (Sharer, 1980):

- kode 3 merupakan pembagian sektor pada suatu lahan. F merupakan kode kotak atau sub-sektor, sedangkan 4 merupakan kode urutan lot per kotak. 
apabila terdapat sekumpulan artefak yang mencerminkan suatu bagian yang utuh, penting. unik, atau merupakan temuan yang satu konteks penggunaannya maka diberi label tersendiri seperti $3 F / 4-1$ ini berarti temuan penting nomor 1 pada kotak F.

\section{Pembahasan}

Pelaksanaan dalam menerapkan sistem lot telah dilakukan pada penelitian di Gua Macan, Dusun Kepel, Desa Lojejer, Kecamatan Wuluhan, Kabupaten Jember, Provinsi Jawa Timur. Berikut akan dibahas mengenai evaluasi pelaksanaan penelitian dengan teknik tersebut.

\section{III.1. Evaluasi pelaksanaan (retrospek).}

Penerapan ekskavasi dengan teknik lot telah diujicobakan pada penelitian dengan tema Pola Pemanfaatan Lahan Gua di Gua Macan. Pada penelitian tersebut telah berhasil membuka empat buah kotak gali. Sebagaimana tujuan dari penelitian ini yaitu untuk mengetahui pengaturan tata ruang yang ada pada lahan gua yang tersedia atau dengan kata lain penelitian mengenai ruang mikro gua.

Dari hasil pengumpulan data tersebut, diketahui bahwa masing-masing lahan digunakan sebagai aktivitas tertentu untuk menunjang aktivitas kehidupan sehari-hari manusia pada masa itu. Pada masing-masing kotak didapatkan informasi bahwa masing-masing memiliki karakter aktivitas sendiri-sendiri. Hal tersebut didapatkan dengan penerapan teknik lot yang sangat membantu dalam pengkelompokkan per temuan pada sekelompok gejala dan aktivitas. Hal tersebut didasarkan pada penerapan prinsip bahwa suatu lot merupakan ruang terkecil atau suatu unit sumber minimum suatu aktivitas (Sharer, 1980).

Berdasarkan prinsip kerja dan pengertian bahwa ruangan terkecil adalah lot, maka didapat informasi semaksimal mungkin mengenai data terkecil pada suatu ekskavasi yang dilakukan. Sejauh ini kendala yang dihadapi adalah yang menyangkut penomoran dan penamaan istilah pada lot per lot. Hal tersebut disebabkan belum adanya pembakuan dalam operasional teknik dari segi dokumentasi baik berupa gambar dan foto maupun penomoran dan pelabelan.

\section{III.2. Prospek untuk penelitian di masa mendatang.}

Berdasarkan evaluasi mengenai penerapan ekskavasi teknik lot pada penelitian di Gua Macan tersebut di atas, maka perlu dilakukan penjabaran dan pembakuan mengenai penerapan teknik lot tersebut, dengan tujuan untuk mempermudah dan memperlancar penerapan teknik tersebut. Secara tegas dapat dikatakan bahwa teknik tersebut sangat tepat diterapkan sehubungan dengan penelitian mengenai arkeologi ruang dalam kajian pola permukiman dengan segala aspeknya. 
Arkeologi ruang dewasa ini memang perlu ditindaklanjuti, hal tersebut disebabkan pada prinsip kehidupan bahwa segala aktivitas manusia akan menghasilkan permukaan yang tidak merata. Metode pengumpulan data yang sesuai adalah dengan melakukan ekskavasi teknik lot sebagaimana yang telah diuraikan di atas. Hal tersebut sangat bermanfaat dan tepat dalam penafsiran mengenai tata ruang suatu pemukiman di mana nantinya akan dapat diambil suatu interpretasi yang akurat dan mampu menjawab semaksimal mungkin informasi yang terkandung di dalamnya. Untuk itu pembakuan dalam peristilahan, penomoran, dan pendokumentasian dalam teknik ini perlu segera dijabarkan dan ditelaah lebih mendalam. Selanjutnya diharapkan pada penelitian-penelitian mendatang mampu dioperasionalkan secara seragam dan baku.

Hal-hal yang masih perlu dibakukan dan dijabarkan lebih lanjut adalah sebagai berikut:

a. nomor temuan penting sehubungan dengan pelabelan dalam lot;

b. nomor lot dalam pemotretan;

c. pencatatan keletakan temuan di dalam lot secara tiga dimensi (pengukuran $\mathrm{X}, \mathrm{Y}, \mathrm{Z}$;

d. pencatatan dan penggambaran lot dalam penyajian akhir; dan

e. temuan-temuan dalam lot yang spesifik dan penting.

\section{Kesimpulan dan Saran.}

Berdasarkan uraian di atas dapat disimpulkan hal-hal sebagai berikut.

1. Pendekatan keruangan dalam mengkaji pola permukiman umumnya dan permukiman gua khususnya perlu ditelaah lebih mendalam. Sehubungan dengan tingkat keruangan yang terbagi dalam tiga tingkat yaitu ruang tingkat mikro, semi mikro (meso), dan makro, maka pola permukiman semakin dapat dijabarkan secara luas dan mendalam.

2. Pendekatan keruangan dalam mengkaji permukiman gua akan mampu terjawab dengan strategi penelitian yang tepat dalam pengumpulan data yang digunakannya. Hal tersebut tergantung pada penjabaran operasional dalam suatu penelitian. Pada tahap survei diharapkan mampu didapatkan suatu luas situs atau suatu komunitas (tingkat ruang meso). Selanjutnya pada tahap ekskavasi diharapkan mampu menjaring informasi pada ruang terkecil dari suatu mikro.

3. Teknik ekskavasi yang sesuai dalam kajian mengenai ruang tingkat mikro dalam hal ini pernukiman gua adalah dengan menggunakan teknik lot. Teknik lot dianggap tepat karena teknik tersebut merupakan ruangan terkecil suatu kegiatan. Selain itu teknik tersebut juga merupakan unit minimum sumber informasi.

4. Sejauh ini dalam penerapan ekskavasi dengan teknik lot masih diperlukan evaluasi yang mendalam dalam penyempurnaannya. Hal-hal yang menjadi 
hambatan dan masalah dalam penerapan teknik tersebut adalah belum adanya pembakuan dalam penomoran dan pendokumentasian untuk menyajikan suatu informasi terkecil. Hal tersebut penting segera dilakukan mengingat informasi terkecil yang didapatkan akan mendukung pembahasan secara mendalam dan luas mengenai pola permukiman khususnya permukiman gua.

5. Perlu adanya pembakuan dan penjabaran mengenai operasional dan penyajian dalam ekskavasi teknik lot ini.

\section{KEPUSTAKAAN}

Chang, K.C., 1968. Settlement in Archaeology, Module in Anthropology, National Press Books, Palo Alto, California.

Clarke, David L., 1977, Spatial Information in Archaeology, in Spatial Archaeology, London : Academic Press, page 1 - 32.

Mundarjito, 1990, Metode Penelitian Permukiman Arkeologi, Monumen Lembaran Sastra Seri Penerbitan Ilmiah No. 11 Edisi Khusus, Depok : Fakultas Sastra UI, hlm. 19 - 31

Philip Barker, 1982. Techniques of Archaeological Excavation, BT. Bastford Ltd. London.

Sharer, Robert J. 1980, Fundamentals of Archaeology, The Benjamin/Commings Publishing Company, Inc.

Subroto, Ph., 1983, Studi Tentang Pola Pemukiman Arkeologi : Kemungkinan Penerapannya di Indonesia, PIA III, Jakarta : Proyek Penelitian dan Penggalian Purbakala, hlm. 1117 - 1186. 